\title{
PENGARUH MODEL PEMBELAJARAN TUTOR SEBAYA DAN MOTIVASI BELAJAR TERHADAP KETERAMPILAN ASUHAN KEHAMILAN
}

\author{
N.K.A. Risnawati ${ }^{1}$, I.G.N. Pujawan ${ }^{2}$, I.G.L.A. Parwata ${ }^{3}$ \\ ${ }^{123}$ Program Studi Penelitian dan Evaluasi Pendidikan \\ Universitas Pendidikan Ganesha \\ Singaraja, Indonesia

\begin{abstract}
e-mail: risnawatiayu01@gmail.com ${ }^{1}$, ngurah.pujawan@undiksha.ac.id ${ }^{2}$, agung.parwata@undiksha.ac.id ${ }^{3}$
\end{abstract}

\begin{abstract}
Abstrak
Penelitian ini bertujuan untuk mengetahui pengaruh model pembelajaran tutor sebaya dan motivasi belajar terhadap keterampilan asuhan kehamilan. Penelitian ini merupakan penelitian experimen dengan treatment by level design. Populasi dalam penelitian ini adalah mahasiswa semester II Prodi DIII Kebidanan FOK Undiksha dengan jumlah 47 mahasiswa. Sampel yang digunakan adalah mahasiswa dengan motivasi tinggi dan motivasi rendah yang diperoleh dari $27 \%$ batas atas dan bawah dengan jumlah sampel 28 mahasiswa. Metode pengumpulan data yang digunakan adalah kuisioner untuk data motivasi belajar dan daftar tilik untuk data asuhan kehamilan. Analisis data yang digunakan yaitu uji ANAVA-AB dan Uji-t. Hasil penelitian menunjukkan bahwa $F_{A}$-hitung diperoleh sebesar 9,875 dan $F_{A B}$-hitung sebesar 38,785 dengan $F$ tabel adalah 4,23 pada taraf signifikasi 0,05 sehingga dapat dinyatakan bahwa keterampilan asuhan kehamilan mahasiswa yang mengikuti model pembelajaran tutor sebaya lebih tinggi daripada mahasiswa yang mengikuti model pembelajaran langsung dan terdapat pengaruh interaksi antara model pembelajaran dan motivasi belajar terhadap keterampilan asuhan kehamilan mahasiswa. Nilai t-hitung $>$ t-tabel $(6,289>1,782)$ dengan taraf signifikasi 0,05 (one tiled) sehingga pada mahasiswa dengan motivasi tinggi, keterampilan asuhan kehamilan mahasiswa yang mengikuti model pembelajaran tutor sebaya lebih tinggi daripada mahasiswa yang mengikuti model pembelajaran langsung. Nilai t-hitung $>\mathrm{t}$-tabel $(2,331>1,782)$ dengan taraf signifikasi 0,05 (satu ekor) yang menunjukkan bahwa pada mahasiswa dengan motivasi rendah, keterampilan asuhan kehamilan mahasiswa yang mengikuti model pembelajaran tutor sebaya lebih rendah daripada mahasiswa yang mengikuti model pembelajaran langsung.
\end{abstract}

Kata kunci: Asuhan Kehamilan; Motivasi Belajar; Tutor Sebaya

\begin{abstract}
This study aims to determine the effect of peer tutoring learning models and learning motivation on pregnancy care skills. This research is an experimental research with treatment by level design. The population in this study were the second semester students of the DIII Midwifery Study Program, FOK Undiksha, with a total of 47 students. The sample used is students with high motivation and low motivation obtained from 27\% upper and lower limits with a sample size of 28 students. Data collection methods used were questionnaires for learning motivation data and checklists for pregnancy care data. The data analysis used was the ANAVA-AB and t-test. The results showed that the FA-count was obtained at 9.875 and the FAB-count was 38.785 with the $F$ table was 4.23 at the 0.05 significance level so that it could be stated that the pregnancy care skills of students who followed the peer tutoring learning model were higher than students who took part in the a direct learning model and there is an influence of the interaction between learning models and learning motivation on students' pregnancy care skills. The value of $t$-counts $t$-table (6.289> 1.782) with a significance level of 0.05 (one tiled) so that for students with high motivation, the pregnancy care skills of students who followed the peer tutor learning model were higher than those who followed the direct learning model. The value of $t$-count $t$-table $(2,331>1,782)$ with a significance level of 0.05 (one tail) which indicates that for students with low motivation, the
\end{abstract}


pregnancy care skills of students who follow the peer tutor learning model are lower than those who follow the direct learning model.

Keywords: Pregnancy Care; Learning Motivation; Peer Tutoring

\section{PENDAHULUAN}

Pendidikan Diploma III Kebidanan merupakan pendidikan Ahli Madya yang mempersiapkan lulusan menguasai kompetensi yang dipersyaratkan sebagai seorang bidan profesional, bekerja secara mandiri, mampu mengembangkan diri dan beretika. Kemajuan ilmu pengetahuan dan teknologi serta tuntutan masyarakat yang semakin kritis terhadap pelayanan kebidanan yang diberikan oleh bidan memberikan konsekuensi bagi lulusan pendidikan kebidanan untuk meningkatkan keterampilan, sikap dan pengetahuannya serta bertindak sesuai dengan kompetensi dan wewenangnya.Dalam upaya mencapai kompetensi lulusan serta mengacu pada karakter pendidikan diploma sebagai pendidikan vokasi maka pada Kurikulum Inti Pendidikan Diploma III Kebidanan ditetapkan persentase pengalaman pembelajaran praktik sebesar $60 \%$. Pembelajaran praktik adalah kegiatan proses pembelajaran praktikum laboratorium $(\mathrm{P})$ dan praktik klinik $(\mathrm{K})$ (PPSDM, 2013). Mahasiswa juga diberikan kesempatan untuk melaksanakan praktik klinik di beberapa rumah sakit dan puskesmas agar dapat mengaplikasikan teori yang telah didapatkan selama perkuliahan pada tatanan yang nyata. Selama melaksanakan praktek klinik kebidanan di rumah sakit dan puskesmas mahasiswa dibimbing oleh pembimbing klinik/rumah sakit yang lebih dikenal dengan Clinical Instructure (Cl). Mahasiswa dibimbing secara bertahap mulai dari bimbingan penuh, bimbingan sebagian dan sampai diberikan melakukan keterampilan secara mandiri. Sebelum bimbingan langsung dengan pasien tentunya $\mathrm{Cl}$ akan melakukan preconference untuk dapat mengetahui pengetahuan awal mahasiswa terkait keterampilan yang akan dilakukan (PPSDM, 2013).

Dari pelaksanaan praktik klinik yang sudah dilakukan mahasiswa selama ini, kemampuan mahasiswa dalam melaksanakan keterampilan asuhan kehamilan ditempat praktek belum optimal. Masih ada mahasiswa yang belum mampu melakukan asuhan kehamilan secara lengkap, sistematis dan fokus pada kasus. Padahal dalam kompetensi Bidan asuhan kehamilan merupakan salah satu kompetensi inti sebagai seorang Bidan. Berdasarkan informasi dari pengajar Mata Kuliah Asuhan Kehamilan pada tanggal 24 Februari 2020 yang diperoleh melalui wawancara disebutkan bahwa dalam 2 tahun terakhir ini jumlah mahasiswa yang remidial saat penilaian/evaluasi praktikum keterampilan asuhan kehamilan di laboratorium sebanyak 10$15 \%$ dilihat dari daftar nilai praktikum Mata Kuliah Asuhan Kehamilan Tahun Akademik 2017/2018 dan 2018/2019 yang menunjukkan bahwa hasil belajar mahasiswa pada mata kuliah asuhan kehamilan belum optimal. Untuk dapat memperoleh hasil belajar yang maksimal sangat diperlukan adanya motivasi yang kuat dari mahasiswa untuk belajar.

Motivasi mahasiswa memiliki peranan penting dalam mencapai tujuan pembelajaran. Adanya motivasi belajar yang tinggi dari mahasiswa akan dapat mempengaruhi usaha atau kegigihannya dalam mencapai tujuan. Dalam pembelajaran keterampilan asuhan kehamilan ini model pembelajaran yang diterapkan adalah model pembelajaran langsung dimana dosen menjelaskan materi kemudian mendemonstrasikan keterampilan asuhan kehamilan yang dilanjutkan dengan demonstrasi dari mahasiswa berdasarkan yang telah didemonstrasikan oleh dosen. Seringkali 
mahasiswa merasa malu dan canggung untuk mendemonstrasikan keterampilan di depan dosen sehingga keterampilan mahasiswa tidak maksimal. Singkatnya waktu pertemuan menyebabkan tidak semua mahasiswa dapat mencoba mendemonstrasikan asuhan kehamilan maka dilanjutkan dengan latihan mandiri di laboratorium diluar jam mata kuliah. Mahasiswa belajar asuhan kehamilan di laboratorium sesuai dengan daya serap atau persepsi yang diterima saat dosen mendemonstrasikan keterampilan di laboratorium dan mahasiswa sangat jarang untuk bertanya kepada dosen walaupun ada hal yang belum dipahami dengan baik. Dengan demikian apabila pemahaman dari mahasiswa tersebut kurang baik, maka keterampilan yang dikuasainya menjadi kurang baik pula.

Keterampilan melakukan asuhan kehamilan dipengaruhi oleh berbagai faktor diantaranya adalah motivasi belajar, model pembelajaran yang digunakan oleh dosen. Berdasarkan hal tersebut, sangat perlu dipikirkan model pembelajaran yang dapat dilakukan untuk meningkatkan keterampilan asuhan kehamilan mahasiswa. Model pembelajaran tutor sebaya dapat diterapkan untuk meningkatkan kemampuan mahasiswa melakukan asuhan kehamilan di laboratorium. Model pembelajaran tutor sebaya ini dapat diterapkan dengan maksimal pada Program Studi DIII Kebidanan mengingatmahasiswa Program Studi Diploma III Kebidanan ini ada yang memiliki kemampuan yang tinggi, menengah dan ada juga yang rendah. Terlihat dari nilai mata kuliah Asuhan Kehamilan yang tertera pada daftar nilai Mata Kuliah Asuhan Kehamilan dalam 3 tahun terakhir (2017 - 2019) dari 194 mahasiswa terdapat 53 mahasiswa $(27,52 \%)$ mendapat nilai $A$ dan A-, sebanyak 85 mahasiswa (43,58\%) dengan nilai $\mathrm{B}$ dan $\mathrm{B}+$, dan masih ada 56 mahasiswa $(28,90 \%)$ dengan nilai $B$-. Dengan demikian dosen dapat memanfaatkan mahasiswa yang memiliki kemampuan tinggi tersebut untuk dapat membantu mahasiswa yang memiliki kemampuan menengah dan yang kurang. Melalui penerapan model pembelajaran tutor sebaya mahasiswa akan berlatih secara berkelompok dan salah satu anggota kelompoknya adalah mahasiswa yang sudah dilatih sebelumnya oleh dosen pengajar. Dalam model pembelajaran tutor sebaya, teman sebaya yang lebih pandai memberikan bantuan belajar kepada teman-teman sekelasnya yang kurang pandai. Bantuan belajar oleh teman sebaya dapat menghilangkan kecanggungan. Bersama teman sebaya diharapkan mahasiswa yang kurang paham tidak segan-segan untuk mengungkapkan kesulitankesulitan yang dihadapinya. Model pembelajaran tutor sebaya adalah model pembelajaran yang terpusat pada mahasiswa, dalam hal ini mahasiswa belajar dari mahasiswa lain yang memiliki status umur dan tingkat kematangan yang tidak jauh berbeda dari dirinya sendiri, sehingga mahasiswa tidak merasa begitu terpaksa untuk menerima ide-ide dan sikap dari tutornya yang tidak lain adalah teman sebayanya itu sendiri.

Berdasarkan uraian latar belakang diatas, peneliti tertarik untuk melakukan penelitian tentang Pengaruh Model Pembelajaran Tutor Sebaya dan Motivasi Belajar terhadap Keterampilan Asuhan Kehamilan pada Mahasiswa Program Studi Diploma III Kebidanan Fakultas Olahraga dan Kesehatan (FOK) Universitas Pendidikan Ganesha.

\section{METODE}

Penelitian ini merupakan penelitian eksperimen dengan desain faktorial yaitu suatu struktur penelitian dimana dua variabel bebas atau lebih saling dihadapkan untuk mengkaji akibatakibatnya yang mandiri dan yang interaktif terhadap satu atau lebih variabel terikat (Dantes, 2017). Adapun desain yang digunakan dalam penelitian ini adalah rancangan dua faktor yakni treatment by level design. Populasi dalam penelitian ini adalah mahasiswa semester II Program Studi DIII Kebidanan Fakultas Olahraga dan 
Kesehatan Undiksha Tahun Akademik 2019/2020 yang terdiri dari 2 kelas dengan jumlah 47 mahasiswa. Sampel yang digunakan dalam penelitian ini adalah mahasiswa dengan motivasi tinggi dan motivasi rendah yang diperoleh dari $27 \%$ batas atas dan bawah pada masing-masing kelas dengan jumlah sampel 28 mahasiswa.

Variabel dalam penelitian ini adalah keterampilan asuhan kehamilan, motivasi belajar, model pembelajaran yang terdiri dari model pembelajaran tutor sebaya dan model pembelajaran langsung. Metode pengumpulan data yang digunakan dalam penelitian ini adalah dengan menyebarkan kuisioner untuk mendapatkan data tentang motivasi belajar dan menggunakan daftar tilik untuk mendapatkan data keterampilan asuhan kehamilan. Kuisioner terdiri dari 30 pernyataan yang disusun dengan kisi-kisi yang mengacu pada unsur-unsur motivasi yang dikemukakan oleh Hamzah (2017). Daftar tilik asuhan kehamilan disusun dengan kisi-kisi yang mengacu pada langkah-langkah pengumpulan data ibu hamil dari Pusdik SDM Kesehatan (2016). Teknik analisis data yang digunakan adalah uji ANAVA-AB dan ujit (Candiasa, 2010).

\section{HASIL DAN PEMBAHASAN}

Sebelum melakukan uji analisis dengan ANAVA-AB dan uji-t terlebih dahulu dilakukan uji normalitas dan homogenitas data. Uji normalitas data dilakukan dengan teknik KolmogorovSmirnov dan uji homogenitas data menggunakan uji Bartlet. Setelah dilakukan uji persyaratan analisis didapatkan bahwa data hasil penelitian berdistribusi normal dan homogen sehingga pengujian hipotesis dengan uji ANAVA-AB dan uji-t dapat dilakukan dan diperoleh hasil sebagai berikut.

Tabel 1. Rangkuman Hasil Uji ANAVA AB

\begin{tabular}{|c|c|c|c|c|c|}
\hline $\begin{array}{l}\text { Sumber } \\
\text { variasi }\end{array}$ & JK & $\mathrm{db}$ & RJK & $F_{h}$ & $\begin{array}{c}\mathrm{F}_{\mathrm{tab}} \\
(\mathrm{Sig} 0,05)\end{array}$ \\
\hline Antar $_{A}$ & 103,926 & 1 & 103,926 & 9,875 & 4,23 \\
\hline $\operatorname{Antar}_{B}$ & 111,775 & 1 & 111,775 & 10,606 & 4,23 \\
\hline Inter $_{A B}$ & 416,138 & 1 & 416,138 & 38,785 & 4,23 \\
\hline dalam & 494,360 & 24 & 11,298 & - & \\
\hline Total & 903,008 & & & & \\
\hline
\end{tabular}

Menurut Joyce \& Weil dalam Parwati dkk (2018) menyatakan bahwa model pembelajaran adalah suatu kerangka konseptual yang menggambarkan prosedur dalam mengorganisir pengalaman belajar untuk mencapai tujuan pembelajaran dan menjadi pedoman bagi perancang pembelajaran. Model pembalajaran tutor sebaya adalah proses belajar mengajar dengan menggunakan bantuan peserta didik yang kompeten untuk mengajarkan peserta didik yang belum kompeten. Dalam model pembelajaran ini menuntut peserta didik untuk aktif mengerjakan tugas sesuai dengan arahan temannya yang kompeten. Dalam proses pembelajaran tutor sebaya ini terlebih dahulu dosen melatih para tutor agar kompeten melakukan asuhan kebidanan pada ibu hamil di laboratorium. Selanjutnya para tutor ini mendemonstrasikan keterampilan asuhan kehamilan yang telah dikuasainya didepan anggota kelompoknya masing-masing yang terdiri dari 4-5 orang sesuai dengan langkah langkah model pembelajaran tutor sebaya (Sani, 2016). Dengan anggota kelompok yang sedikit, maka saat tutornya mendemonstrasikan keterampilan akan dilihat dengan sangat jelas oleh anggota kelompoknya yang hanya empat orang tersebut. Saat 
redemonstrasi pun kesempatan untuk mencoba akan menjadi semakin banyak dan tutor akan intensif melatih temannya. Tutor diberikan tangggung jawab oleh Dosen untuk melatih anggota kelompoknya sampai semuanya kompeten.

Seseorang akan menjadi terampil apabila keterampilan tersebut sering dilakukan dan didampingi oleh seseorang yang memang memahami keterampilan tersebut. Pada model pembelajaran tutor sebaya mahasiswa saat melakukan latihan asuhan kehamilan didampingi oleh mahasiswa yang telah mendapat bimbingan dari dosen sehingga tentunya keterampilannya akan semakin baik. Keadaan ini terjadi karena adanya bantuan belajar oleh tutor sebaya dapat menghilangkan kecanggungan. Dengan teman sebaya tidak ada rasa enggan, dan malu sehingga mahasiswa yang kurang paham tidak segan-segan untuk mengungkapkan kesulitan-kesulitan yang dihadapinya (Suryono dan Amin dalam Setiadiwijaya, 2012).

Berdasarkan hasil analisis data dengan uji ANAVA $A B$ diperoleh nilai signifikansi $F_{A}$ yaitu 0,004 jauh lebih kecil daripada taraf signifikansi yang ditetapkan yaitu 0,05 sehingga terdapat perbedaan keterampilan asuhan kehamilan antara kelompok mahasiswa dengan model pembelajaran tutor sebaya dengan kelompok mahasiswa dengan model pembelajaran langsung. Berdasarkan nilai rata rata, nilai keterampilan asuhan kehamilan pada kelompok model pembelajaran tutor sebaya yaitu 82,85 dan rata rata nilai keterampilan asuhan kehamilan pada kelompok model pembelajaran langsung yaitu 79,00 yang menunjukkan bahwa rata rata nilai keterampilan asuhan kehamilan pada kelompok model pembelajaran tutor sebaya lebih tinggi daripada rata rata nilai keterampilan asuhan kehamilan pada kelompok model pembelajaran langsung. Dengan demikian dapat dinyatakan bahwa keterampilan asuhan kehamilan mahasiswa yang mengikuti model pembelajaran tutor sebaya lebih tinggi daripada mahasiswa yang mengikuti model pembelajaran langsung.

Hal ini didukung pula dari hasil penelitian yang dilakukan Anggraini dan Rahayu (2016) ditemukan bahwa metode tutor sebaya efektif meningkatkan pencapaian kompetensi Asuhan Persalinan Normal pada pembelajaran laboratorium di Prodi DIII Kebidanan UNUSA. Begitu pula penelitian yang dilakukan oleh Isnaini (2019) menunjukkan bahwa terdapat pengaruh metode tutor sebaya terhadap hasil belajar senam nifas mahasiswa semester II program studi D-III Kebidanan Dian Husada Mojokerto. Penelitian yang dilakukan oleh Wahyuningsih (2011) menunjukkan bahwa penggunaan metode pembelajaran tutor sebaya dapat meningkatkan prestasi nilai praktek prepare dan table service pada mahasiswa S1 semester IV Prodi Teknologi Jasa dan Produksi Boga, Jurusan Teknologi Jasa dan Produksi, Fakultas Teknik Universitas Negeri Semarang.

Motivasi belajar merupakan dorongan yang terdapat dalam diri seseorang untuk berusaha mengadakan perubahan tingkah laku yang lebih baik dalam memenuhi kebutuhannya (Hamzah, 2017). Model pembelajaran tutor sebaya dan model pembelajaran langsung menunjukkan penekanan esensi yang berbeda. Dalam model pembelajaran tutor sebaya cendrung berpusat pada mahasiswa, sedangkan model pembelajaran langsung berpusat pada dosen. Pada model pembelajaran yang berpusat pada mahasiswa, menuntut mahasiswa untuk aktif berpartisipasi dalam keseluruhan proses pembelajaran, sedangkan pada model pembelajaran yang berpusat pada dosen, yang memegang kendali dalam keseluruhan proses pembelajaran adalah dosen. Perbedaan esensi kedua model pembelajaran ini memerlukan pertimbangan dalam penerapannya salah satunya adalah motivasi belajar mahasiswa. Tinggi rendahnya motivasi 
belajar mahasiswa akan menentukan hasil belajarnya. Model pembelajaran tutor sebaya lebih cocok diterapkan pada mahasiswa dengan motivasi belajar tinggi sedangkan model pembelajaran langsung lebih tepat diterapkan pada mahasiswa dengan motivasi rendah.

Berdasarkan hasil penelitian diperoleh nilai signifikansi $F_{A B}$ yaitu 0,000 jauh lebih kecil daripada taraf signifikansi yang ditentukan yaitu 0,05.
Ini menunjukkan bahwa terdapat interaksi antara model pembelajaran dan motivasi belajar terhadap keterampilan asuhan kehamilan mahasiswa Program Studi Dilpoma III Kebidanan. Hasil penelitian ini sesuai dengan penelitian yang dilakukan oleh Ulfa dkk (2014) menyebutkan bahwa terdapat pengaruh interaksi antara model pembelajaran dengan motivasi berprestasi siswa terhadap hasil belajar TIK.

Tabel 2. Rangkuman Hasil Uji-t pada Mahasiswa dengan Motivasi Tinggi

\begin{tabular}{cccccc}
\hline Sampel & $\mathrm{N}$ & $\mathrm{dk}$ & $\bar{X}$ & $\mathrm{t}_{\text {hitung }}$ & $\begin{array}{c}\mathrm{t}_{\text {tabel }} 5 \% \\
\text { (satu ekor) }\end{array}$ \\
\hline $\begin{array}{c}\text { Kelompok dengan } \\
\text { model pembelajaran } \\
\begin{array}{c}\text { tutor sebaya } \\
\text { Kelompok dengan } \\
\text { model pembelajaran } \\
\text { langsung }\end{array}\end{array}$ & 7 & 12 & 88,71 & 6,289 & 1,782 \\
\hline
\end{tabular}

Motivasi merupakan dorongan yang terdapat dalam diri seseorang untuk berusaha mengadakan perubahan tingkah laku yang lebih baik dalam memenuhi kebutuhannya (Hamzah, 2017). Hakikat motivasi belajar adalah dorongan internal dan eksternal siswa yang sedang belajar untuk mengadakan perubahan tingkah laku. $\mathrm{Hal}$ itu mempunyai peranan besar dalam keberhasilan seseorang dalam belajar. Motivasi belajar tentunya akan mampu mempengaruhi keterampilan seseorang, karena untuk menjadi terampil seseorang harus sering melakukan keterampilan tersebut. Apabila motivasi belajar seseorang tinggi maka ia akan semakin gigih dan ulet untuk belajar agar menjadi terampil. Ditambah lagi dengan penerapan model pembelajaran tutor sebaya maka mahasiswa yang memiliki motivasi tinggi akan semakin senang belajar dengan teman sebayanya untuk terus saling berdiskusi tanpa rasa canggung dan dalam suasana yang akrab. Dengan demikian maka akan dapat meningkatkan keterampilan asuhan kehamilannya. Menurut Suryono dan Amin dalam
Setiadiwijaya (2012) menyatakan bahwa melalui model pembelajaran tutor sebaya maka akan tercipta suasana hubungan yang lebih akrab dan dekat antara mahasiswa yang dibantu dengan mahasiswa sebagai tutor yang membantu sehingga mahasiswa belajar dengan lebih santai namun bermakna. .

Berdasarkan hasil penelitian pada mahasiswa dengan motivasi tinggi diperoleh rerata nilai yang lebih tinggi pada kelompok yang mengikuti model pembelajaran langsung daripada mahasiswa yang mengikuti model pembelajaran langsung ( $\bar{X}_{\text {eksperimen }}=$ $\left.88,71>\bar{X}_{\text {kontrol }}=77,14\right)$. Dari hasil uji statistik dengan uji-t diperoleh hasil yaitu t-hitung $>$ t-tabel $(6,289>1,782)$ dengan taraf signifikasi 0,05 (satu ekor) yang berarti bahwa pada mahasiswa yang memiliki motivasi belajar tinggi, keterampilan asuhankehamilan kelompok mahasiswa dengan pembelajaran tutor sebaya lebih tinggi daripada kelompok mahasiswa dengan model pembelajaran langsung. Model pembelajaran tutor sebaya merupakan salah satu model pembelajaran kooperatif yang sangat cocok diterapkan 
pada mahasiswa dengan motivasi tinggi.

Penelitian yang dilakukan oleh Ulfa dkk (2014) juga menunjukkan bahwa hasil belajar TIK untuk siswa yang memiliki motivasi berprestasi tinggi yang mengikuti model pembelajaran tutor sebaya lebih unggul dibandingkan dengan siswa yang memiliki motivasi berprestasi tinggi yang mengikuti model pembelajaran konvensional.

Tabel 3 Rangkuman Hasil Uji-t pada Mahasiswa dengan Motivasi Rendah

\begin{tabular}{cccccc}
\hline Sampel & $\mathrm{N}$ & $\mathrm{dk}$ & $\bar{X}$ & $\mathrm{t}_{\text {hitung }}$ & $\begin{array}{c}\mathrm{t}_{\text {tabel }} 5 \% \\
\text { (satu ekor) }\end{array}$ \\
\hline $\begin{array}{c}\text { Kelompok dengan } \\
\text { model pembelajaran } \\
\text { tutor sebaya }\end{array}$ & 7 & 12 & 77,00 & 2,331 & 1,782 \\
$\begin{array}{c}\text { Kelompok dengan } \\
\text { model pembelajaran } \\
\text { langsung }\end{array}$ & 7 & & 80,68 & & \\
\hline
\end{tabular}

Motivasi yang rendah akan menyebabkan mahasiswa enggan untuk belajar. Mahasiswa tidak memiliki inisiatif yang baik untuk mencari tahu dari teman ataupun dari dosennya. Mahasiswa akan sangat bergantung pada materi yang diberikan oleh dosen saja tanpa berusaha untuk menambah kemampuannya melalui sumber belajar yang lain. Mahasiswa yang memiliki motivasi rendah merasa nyaman dengan model pembelajaran langsung karena tinggal menunggu arahan dari dosen saja tanpa harus bersusah payah untuk mencari sumber belajar yang lainnya. Mahasiswa hanya cukup mencoba mendemonstrasikan kembali keterampilan yang telah didemonstrasikan oleh dosen. Dengan demikian saat proses pembelajaran langsung dilaksanakan mereka akan fokus pada dosennya dan mengikuti semua hal yang telah didemonstrasikan oleh dosennya. Mahasiswa akan mau mendemonstrasikan kembali keterampilan yang tadinya telah ditunjukkan oleh dosen karena tidak berani menolak sehingga mau tidak mau mereka akan berlatih.

Pada model pembelajaran tutor sebaya sangat diperlukan keaktifan dan kerjasama mahasiswa dengan tutornya sehingga keterampilan asuhan kehamilan yang dikuasai semakin baik. Sehingga pada mahasiswa dengan motivasi yang rendah sering kewalahan dalam mengikuti proses pembelajaran dengan model tutor sebaya. Mereka cendrung lebih pasif menunggu arahan dari tutornya saja. Hal ini memungkinkan keterampilan yang dimiliki oleh mahasiswa tidak maksimal. Mahasiswa dengan motivasi rendah cendrung memberikan kesempatan yang lebih banyak kepada mahasiswa lainnya untuk berlatih saat pembelajaran tutor sebaya berlangsung.

Model pembelajaran langsung memang lebih tepat diterapkan pada mahasiswa dengan motivasi belajar rendah. Hal ini sesuai dengan salah satu kelebihan dari model pembelajaran langsung yang dikemukakan oleh Lefudin (2004) yakni dapat digunakan untuk mengajarkan konsep dan keterampilan yang eksplisit kepada mahasiswa yang memiliki motivasi berprestasi rendah. Kondisi ini yang menyebabkan pada mahasiswa dengan motivasi belajar yang rendah, nilai keterampilan asuhan kehamilan mahasiswa yang mengikuti model pembelajaran tutor sebaya lebih rendah daripada mahasiswa yang mengikuti model pembelajaran langsung $\left(\bar{X}_{\text {eksperimen }}\right.$ $=77,00<\bar{X}_{\text {kontrol }}=80,86$ ). Hasil uji statistik juga menunjukkan nilai t-hitung $>$ t-tabel $(2,331>1,782)$ dengan taraf signifikasi 0,05 (satu ekor) yang berarti bahwa pada mahasiswa yang memiliki motivasi belajar rendah, keterampilan asuhan kehamilan kelompok mahasiswa 
dengan pembelajaran tutor sebaya lebih rendah daripada kelompok mahasiswa dengan model pembelajaran langsung.

Hasil penelitian ini didukung pula oleh penelitian yang dilakukan oleh Ulfa dkk (2014) yang menyatakan bahwa pada siswa yang memiliki motivasi berprestasi rendah terdapat perbedaan hasil belajar TIK yang signifikan antara yang mengikuti model pembelajaran tutor sebaya dengan siswa yang mengikuti model pembelajaran konvensional. Dan hasil belajar TIK siswa yang memiliki motivasi berprestasi rendah yang mengikuti model pembelajaran konvensional lebih tinggi dibandingkan dengan hasil belajar TIK siswa yang memiliki motivasi berprestasi rendah yang mengikuti model pembelajaran tutor sebaya.

\section{PENUTUP}

Berdasarkan hasil uji statistik tersebut diatas dapat disimpulkan bahwa: 1) keterampilan asuhan kehamilan mahasiswa yang mengikuti model pembelajaran tutor sebaya lebih tinggi daripada mahasiswa yang mengikuti model pembelajaran langsung; 2) terdapat pengaruh interaksi antara model pembelajaran dan motivasi belajar terhadap keterampilan asuhan kehamilan mahasiswa; 3) pada mahasiswa dengan motivasi tinggi, keterampilan asuhan kehamilan mahasiswa yang mengikuti model pembelajaran tutor sebaya lebih tinggi daripada mahasiswa yang mengikuti model pembelajaran langsung; 4) pada mahasiswa dengan motivasi rendah, keterampilan asuhan kehamilan mahasiswa yang mengikuti model pembelajaran tutor sebaya lebih rendah daripada mahasiswa yang mengikuti model pembelajaran langsung.

Berdasarkan simpulan tersebut maka sangat diharapkan kepada mahasiswa agar selalu berlatih dengan giat agar keterampilan yang berkaitan dengan kebidanan khususnya asuhan kehamilan dapat semakin meningkat serta selalu berupaya membangkitkan motivasi belajar terutama dari segi intrinsik sebagai modal awal dalam upaya mencapai hasil belajar yang optimal. Berlatih keterampilan dapat dilakukan tidak saja dengan dosen tetapi dapat pula berlatih dengan teman sebaya. Kepada dosen diharapkan agar senantiasa mendorong mahasiswa untuk melakukan praktek dengan sungguh sungguh dengan berupaya membangkitkan motivasi belajar mahasiswa melalui penerapan berbagai model pembelajaran yang menarik minat mahasiswa dan dalam memilih model pembelajaran yang digunakan terlebih dahulu memperhatikan motivasi belajar dari mahasiswa.

\section{DAFTAR RUJUKAN}

Anggraini \& Rahayu. 2016. "Efektivitas Metode Tutor Sebaya Dalam Pencapaian Kompetensi Asuhan Persalinan Normal Pada Pembelajaran Laboratorium Di Prodi DIII Kebidanan UNUSA", Jurnal IImiah Kesehatan Vol 9 No 2.

Candiasa, I., M. 2010. Statistik Univariat dan Bivariat disertai Aplikasi SPSS. Singaraja: Undiksha.

Dantes., N. 2017. Desain Eksperimen dan Analisis Data. Depok: PT RajaGrafindo.

Hamzah. 2017. Teori Motivasi dan Pengukurannya. Jakarta: Bumi Aksara

Isnaini. 2019. "Pengaruh Metode Pembelajaran Tutor Sebaya Terhadap Hasil Belajar Materi Senam Nifas Pada Mahasiswa D-III Kebidanan ". Midwifery Journal of STIKes Insan Cendekia Medika Jombang Vol 17 No 1.

Kurikulum Pendidikan Diploma III Kebidanan Tahun 2016

Lefudin. 2014. Belajar dan Pembelajaran. Yogyakarta: Deepublish.

Parwati dkk. 2018. Belajar dan Pembelajaran. Depok: PT RajaGrafindo Persada. 
PPSDM. 2013. Pedoman Pelaksanaan Praktik Klinik Kebidanan. Jakarta Kementrian Kesehatan Republik Indonesia.

Pusdik SDM Kesehatan. 2016. Modul Bahan Ajar Cetak Kebidanan: Praktek Klinik Kebidanan III. Jakarta. Kementrian Kesehatan Republik Indonesia.

Sani, Ridwan Abdullah. 2016. Inovasi Pembelajaran. Jakarta: Bumi Aksara.

Sugiono. 2018. Statistik Untuk Penelitian. Bandung: Alfabeta.

Ulfa dkk. 2014. "Pengaruh Penerapan Model Pembelajaran Kooperatif
Teknik Tutor Sebaya Terhadap Hasil Belajar TIK Ditinjau Dari Motivasi Berprestasi Pada Siswa Kelas VI SD Muhammadiyah 2 Denpasar". pada e-Journal Program Pascasarjana Universitas Pendidikan Ganesha Program Studi Pendidikan Dasar (Volume 4 Tahun 2014).

Wahyuningsih. 2011. "Penerapan Metode Tutor Sebaya untuk Meningkatkan Keterampilan Prepare Dan Table Set Up dalam Mata Kuliah Tata Hidang" Jurnal Penelitian dan Pendidikan $\left(\begin{array}{llll}\mathrm{Vol} & 28 & \text { No } & 1\end{array}\right)$. 